\title{
Variation of accumulation rates over the last eight centuries 2 on the East Antarctic Plateau derived from volcanic signals in ice cores
}

H. Anschütz, ${ }^{1,6}$ A. Sinisalo, ${ }^{2}$ E. Isaksson, ${ }^{1}$ J.R. McConnell, ${ }^{3}$ S.-E. Hamran, ${ }^{2,4}$

M.M. Bisiaux,${ }^{3}$ D. Pasteris, ${ }^{3}$ T.A. Neumann ${ }^{5}$ and J.-G. Winther ${ }^{1}$

Helgard Anschütz, Norwegian Polar Institute, Fram Centre, N-9296 Tromsø, Norway (helgard.anschuetz@npolar.no)

${ }^{1}$ Norwegian Polar Institute, Troms $\varnothing$, Norway

${ }^{2}$ Department of Geosciences, University of

Oslo, Norway

${ }^{3}$ Desert Research Institute, Division of

Hydrologic Sciences, Reno, NV, USA

${ }^{4}$ Forsvarets Forskningsinstitutt, Lillestrøm,

Norway

${ }^{5}$ NASA Goddard Space Flight Center,

Greenbelt, MD, USA

${ }^{6}$ now at Norwegian Geotechnical Institute,

Oslo, Norway

D $\quad R \quad A \quad F \quad T$

July 19, 2011, 1:46pm

$\begin{array}{lllllllllllllll}D & R & A & F & T\end{array}$ 
${ }_{4}$ Abstract. Volcanic signatures in ice-core records provide an excellent means

5 to date the cores and obtain information about accumulation rates. From sev-

6 eral ice cores it is thus possible to extract a spatio-temporal accumulation pat-

7 tern. We show records of electrical conductivity and sulfur from 13 firn cores

8 from the Norwegian-USA scientific traverse during the International Polar Year

9 2007-2009 (IPY) through East Antarctica. Major volcanic eruptions are iden-

10 tified and used to assess century-scale accumulation changes. The largest changes

11 seem to occur in the most recent decades with accumulation over the period 1963-

${ }_{12} 2007 / 08$ being up to $25 \%$ different from the long-term record. There is no clear

13 overall trend, some sites show an increase in accumulation over the period 1963

14 to present while others show a decrease. Almost all of the sites above $3200 \mathrm{~m}$

15 above sea level (asl) suggest a decrease. These sites also show a significantly

16 lower accumulation value than large-scale assessments both for the period 1963

17 to present and for the long-term mean at the respective drill sites. The spatial

18 accumulation distribution is influenced mainly by elevation and distance to the

19 ocean (continentality), as expected. Ground-penetrating radar data around the

${ }_{20}$ drill sites show a spatial variability within $10-20 \%$ over several tens of kilo-

${ }_{21}$ meters, indicating that our drill sites are well representative for the area around

${ }_{22}$ them. Our results are important for large-scale assessments of Antarctic mass

${ }_{23}$ balance and model validation. 


\section{Introduction}


45 [2009] conclude that studies on Antarctic mass balance employing glaciological field data, e.g.

${ }_{46}$ Vaughan et al. [1999], give the most reliable results. Genthon and Krinner [2001] explain that

47 especially the regions devoid of field observations introduce large errors in modeled assessments

48 of a continent-wide accumulation pattern. Thus, it is important to obtain ground-truth for large-

49 scale estimates of Antarctic mass changes.

The Norwegian-USA scientific IPY 2007-2009 traverse through East Antarctica aims to con-

${ }_{51}$ tribute a set of field data comprising among others firn-core records and ground-penetrating

${ }_{52}$ radar (GPR) data and thus help understanding the status of the East Antarctic ice sheet and

53 its changes on scales of a few decades to more than one millennium. The traverse went from

${ }_{54}$ Norwegian Troll Station to South Pole in the austral summer 2007/08 and back on a different

${ }_{55}$ route via the Recovery Lakes area in 2008/09 (see Figure 1). We will refer to the route taken

${ }_{56}$ in $2007 / 08$ as the first leg and the route from $2008 / 09$ as the second leg in this paper. Together

${ }_{57}$ the two consecutive traverse legs covered large parts of the interior of Dronning Maud Land.

${ }_{58}$ Along the route shallow $(20-30 \mathrm{~m})$ and intermediate-depth $(80-90 \mathrm{~m})$ firn cores were drilled

59 of which we present 13 records in total ( 9 shallow and 4 intermediate-depth). All the drill sites

60 were linked by GPR data [Müller et al., 2010].

Firn and ice cores are a valuable climate archive, allowing scientists to research climate vari62 ations as far back as 800000 years [Lambert et al., 2008]. For the purpose of determining accumulation rates, mostly chemical species are used, often in conjunction with oxygen isotope ${ }_{64}$ data and electrical conductivity. Since all of these records tend to show an annual variation, they 65 allow for identification of summer or winter peaks (depending on the species considered) and ${ }_{66}$ hence annual dating. However, in very low accumulation areas like the East Antarctic interior, an annual signal might not be preserved. Hence, identification of time markers is crucial in these 
${ }_{68}$ areas for accumulation determination. Here, we focus on chemistry data (sulfur and sodium) and electrical conductivity to date the 13 firn cores by identifying known volcanic eruptions.

70 This enables the calculation of accumulation rates and variability for the time periods between 71 major eruptions.

\section{Data and Methods}

72 The firn cores NUS07-3, $-4,-6$, and -8 (Figure 1) from the first leg were analysed in the cold 73 laboratory at Norwegian Polar Institute in Troms $\emptyset$ using the dielectric profiling (DEP) technique 74 [Moore et al., 1991; Wilhelms et al., 1998]. From the measured capacitance and conductance we 75 derived dielectric permittivity and electrical conductivity. The records have been presented and 76 discussed in Anschütz et al. [2009] where we also give some more details about the measuring 77 technique. The firn cores NUS07-1, $-2,-5$ and -7 were analysed for chemical composition (Figures 2 and 3) at the Desert Research Institute (DRI) in Reno, USA, using a sophisticated 79 combination of continuous-flow analysis and mass spectrometry [McConnell et al., 2002]. The 80 record of NUS07-1 has also been shown by Anschütz et al. [2009] where sulfur, sodium and ${ }_{81}$ electrolytical conductivity (i.e., the conductivity of the meltwater) are discussed for this core. ${ }_{82}$ Note that this core is named "site I" in Anschütz et al. [2009] due to a nomenclature of drill sites ${ }_{83}$ used during the expedition. The name has since been changed to "NUS07-1" for the sake of ${ }_{84}$ consistency and we therefore also refer to this core as NUS07-1 here.

85 From the second leg the firn cores NUS08-2, -3, -4, and -6 were analysed using DEP (Figure ${ }_{86} 4$ ) and cores NUS08-4 and -5 for chemistry (Figure 5). From the large amount of species 87 measured by the device at DRI we use sulfur and sodium here. The sodium records were used s8 to calculate non-sea-salt (nss) sulfur (see e.g. Traufetter et al. [2004]) which differs less than 89 $10 \%$ from the total sulfur at these inland sites. In the following we will refer to the nss-sulfur 
90 data as the "sulfur records" only. The DEP and sulfur records allow for detection of volcanic

${ }_{91}$ peaks as shown by several studies on Antarctic and Greenland ices cores [Hofstede et al., 2004;

${ }_{92}$ Traufetter et al., 2004; Langway et al., 1995; Cole-Dai et al., 2000]. We follow the criterion

93 outlined by Cole-Dai et al. [1997] and other authors for identification of a volcanic peak: First,

94 the large peaks likely stemming from volcanic input were removed from the records. Second,

${ }_{95}$ the mean (background value) and standard deviation were calculated. For a peak to qualify as a

${ }_{96}$ volcanic eruption it has to fulfill two criteria: (1) the value has to be at or above two times the

${ }_{97}$ standard deviation and (2) has to stay at that level for at least two consecutive samples, in order

98 to exclude outliers in the measurement. As the electrical conductivity increases with depth, we

99 followed the method outlined by Karlöf et al. [2000] and other authors and normalized the DEP

100 data by first detrending the conductivity records and then dividing by the standard deviation.

101 Again, a peak has to be at or above two times the standard deviation for at least two samples.

102 In order to derive accumulation rates from the dated horizons, information about density is needed. We measured the bulk density in the field and fitted a third order polynomial to these values [Ren et al., 2010] to obtain a smooth density distribution. Often the Looyenga-based density is used for accumulation calculation where DEP data are measured [Anschütz et al., 2009; Hofstede et al., 2004]. However, we do not have DEP data available for the chemistry cores, therefore the bulk density was used here. A comparison between Looyenga-based density and bulk density for the DEP cores yields an average difference of 3-4\%, comparable to the values reported by Hofstede et al. [2004].

Error estimation follows the discussion by Anschütz et al. [2009] and Müller et al. [2010]:

We assume an age uncertainty of three years between volcanic horizons (discussed below in more detail) [Traufetter et al., 2004; Hofstede et al., 2004], a depth error of two centimeters 


\section{Results}


has been detected in several ice cores around the continent [Traufetter et al., 2004; Hofstede et al., 2004; Karlöf et al., 2000]. The unknown peak from 1695 is reported by several authors, with slightly different dates, varying from 1693-1697 [Ren et al., 2010; Hofstede et al., 2004; Cole-Dai et al., 2000; Budner and Cole-Dai, 2003]. Here, we use 1695 as the eruption date in accordance with Hofstede et al. [2004] and Anschütz et al. [2009]. The subantarctic volcano of Deception Island erupted in 1641 [Aristarain and Delmas, 1998], however, some authors ascribe a signal at that time to the eruption of Awu (Sangihe Islands, Indonesia) [Stenni et al., 2002; Karlöf et al., 2000] or Mount Parker (Philippines) [Cole-Dai et al., 2000; Traufetter et al., 2004]. Most likely, the signal is an overlap of several eruptions. Since Deception Island is the closest one to the Antarctic continent, we attribute the 1641 peak to this volcano. Another unknown eruption occurred in 1622 [Hofstede et al., 2004], and in 1600 Huaynaputina (Peru) erupted, being also visible in several ice cores [Cole-Dai et al., 2000; Karlöf et al., 2000; Budner and Cole-Dai, 2003]. Here, we use the Huaynaputina peak where it is detectable and Deception Island or Unknown 1622 for cores that do not quite reach back to 1600 . Before 1600 dating is less certain due to the sparsity of historic documentation of volcanic eruptions [Traufetter et al., 2004]. However, some prominent peaks have been dated in deeper ice cores and allow us to assume reliable dating for several of our observed peaks as well. The eruption of Kuwae (Vanuatu, southwest Pacific) in 1453 is easily identified in ice cores from both hemispheres [Langway et al., 1995; Oerter et al., 2000; Karlöf et al., 2000; Ren et al., 2010] and in some studies it provided the largest peak in the entire record [Gao et al., 2006; Palmer et al., 2001]. The eruption of El Chichon (Mexico) in 1342 is seen less often than the one of Kuwae, but some authors report prominent peaks for this eruption as well [Budner and Cole-Dai, 2003; Karlöf 
DEP cores. Where identification is somewhat questionable due to noisy data or small peaks, a question marked is depicted in the respective figures. In the chemistry cores from the first leg the Agung peak is much smaller than the very prominent earlier peaks like Tambora and Kuwae. Thus, due to the scaling of the full record the Agung peak does not depict very well and therefore we show in addition a figure of the top meters of these records where Agung is visible (Figure 3). The accumulation rates averaged over the time periods between the respective volcanic horizons are depicted in Figures 7 and 8.

All the data from the first leg exhibit a slight decrease in accumulation since 1963, with the exception of the northernmost site NUS07-1 (Figure 7). NUS07-3 shows a very slight increase over the period 1963-2007 in comparison with 1883-1963, however, this increase is within the range of uncertainty. For the majority of the sites (NUS07-2, -4, -5, -7 and -8) the accumulation between 1963-2007 is the lowest in comparison to the other time periods considered in the respective record. NUS07-6 (depicted in Anschütz et al. [2009]) does not show the eruption of Agung due to lower core quality in the top meters, therefore only the period 1883-2007 is considered, which again reveals the lowest accumulation in the entire record from this site (Figure 7). These results show that virtually all of the highest elevation sites (above $3200 \mathrm{~m}$ ) reveal a decreasing trend of accumulation over the last decades. This is in accordance with the findings of Isaksson et al. [1999] who report accumulation values from firn cores along a traverse line from the grounded coastal area up to the Amundsenisen plateau in Dronning Maud Land. They find that accumulation has been decreasing over the time period 1965-1996 for sites above $3250 \mathrm{~m}$ and mostly increasing below. Hence, they conclude that an accumulation increase as reported for instance by Mosley-Thompson et al. [1999]; Hofstede et al. [2004]; Oerter et al. [2000] is not necessarily valid for the whole plateau area of Dronning Maud Land. 


\subsection{Spatial variability}

The South-Pole Queen Maud Land Traverses (SPQMLT) went through large parts of Dronning Maud Land in the 1960s [Picciotto et al., 1971] and some of their sampling sites are relatively close to our drill sites (see Figure 1). They determined accumulation rates from snow-pit stratigraphy and at selected sites additionally from measurements of radioactivity, discovering fallout from nuclear tests in the 1950s and 1960s. Anschütz et al. [2009] compare accumulation values from the first leg with SPQMLT data and find that accumulation in this area is lower than reported by SPQMLT. For sites close to the area visited during the second leg of the traverse, Picciotto et al. [1971] report an accumulation value of $38 \mathrm{~kg} \mathrm{~m}^{-2} \mathrm{a}^{-1}$ for their site SPQMLT-2-12 which is $31 \mathrm{~km}$ from our site NUS08-5 and $33 \mathrm{~km}$ from NUS08-4. The value of $37.6 \mathrm{~kg} \mathrm{~m}^{-2} \mathrm{a}^{-1}$ at site NUS08-5 thus is in good agreement, whereas NUS08-4 shows a slightly lower value of $36.1 \mathrm{~kg} \mathrm{~m}^{-2} \mathrm{a}^{-1}$. For their site SPQMLT-2-16, $22 \mathrm{~km}$ from our site NUS08-6, Picciotto et al. [1971] obtain $35 \mathrm{~kg} \mathrm{~m}^{-2} \mathrm{a}^{-1}$. Here, our results are higher with $49.2 \mathrm{~kg} \mathrm{~m}^{-2} \mathrm{a}^{-1}$, yet this is one of the sites where a recent accumulation increase occurs. The 200-year mean of $39.2 \mathrm{~kg} \mathrm{~m}^{-2} \mathrm{a}^{-1}$ is in better agreement with the results of Picciotto et al. [1971]. However, one should bear in mind that comparison is limited due to large spatial distances and different time periods. Moreover, Magand et al. [2007] demonstrate that older data sets, like some of the SPQMLT data, are often biased and tend to overestimate accumulation on the polar plateau.

In general, the spatial representativity of point measurements such as firn-core records can be assessed by GPR data. For the first leg, Anschütz et al. [2009] show $5.3 \mathrm{GHz}-\mathrm{GPR}$ data around the sites NUS07-4 and -6 and find a general variability of about 10-20\% over several tens of kilometers for the Tambora layer. Müller et al. [2010] follow GPR layers over an $860 \mathrm{~km}$ 
${ }_{314}$ cumulation is mostly higher for sites on the second leg than on the first. This is clearly related 315 to elevation differences (Table 3). The accumulation over parts of the Recovery Lakes area ${ }_{316}$ (NUS08-4 and -5) is in the range of the higher values of the first leg. In general, accumulation 317 is very low on the high East Antarctic plateau, for parts of the first leg even lower than expected

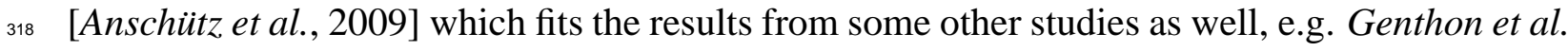
319 [2009].

Several large-scale assessments have been carried out in order to derive a spatial pattern of accumulation for the entire Antarctic ice sheet, e.g. by Vaughan et al. [1999]; Giovinetto and Zwally [2000]; Arthern et al. [2006]; Monaghan et al. [2006]; van de Berg et al. [2006]. Even 323 though a detailed comparison is limited due to the resolution of these studies (typically around $50-100 \mathrm{~km}$ or more), it is interesting to compare values for the area around our drill sites based $-4,-6$ and -8 for the period 1815-2007 in comparison to the results by Monaghan et al. [2006] and Arthern et al. [2006]. They find lower in-situ values than these two studies. Müller et al. [2010] derive accumulation averaged over the time period 1815-2007 along an $860 \mathrm{~km}$ GPR profile for the first leg and likewise find lower values compared to the studies by Monaghan et al. [2006], Arthern et al. [2006] and van de Berg et al. [2006]. They conclude that this might support the suggestion that accumulation has been increasing for much of the East Antarctic plateau over the last 50 years, as the studies by Arthern et al. [2006] and Monaghan et al. [2006] represent largely this time period. This finding is not supported by our firn-core data from the first leg, highlighting again the complexity of the temporal accumulation behavior and the difficulties to draw conclusions for a large area from single drill sites. 
cial thanks to the traverse teams. K. Langley and S. Tronstad (Norwegian Polar Institute) helped with Figure 1.

\section{References}

Alley, R., P. Clark, P. Huybrechts and I. Joughin, Ice-sheet and sea-level changes, Science, 310(5747), 456-460, 2005.

Anschütz, H., K. Müller, E. Isaksson, J. McConnell, H. Fischer, H. Miller, M. Albert and J.G. Winther, Revisiting sites of the South Pole Queen Maud Land Traverses in East Antarctica: Accumulation data from shallow firn cores, J. Geophys. Res., 114, D24106, 2009.

Aristarain, A. and R. Delmas, Ice record of a large eruption of Deception Island Volcano (Antarctica) in the XVIIth century, Journal of Volcanology and Geothermal Research, 80, $17-25,1998$.

Arthern, R., D. Winebrenner, and D. Vaughan, Antarctic snow accumulation mapped using polarization of 4.3cm-wavelength emission, J. Geophys. Res., 111, D06107, 2006.

Budner, D., and J. Cole-Dai, The number and magnitude of large explosive volcanic eruptions between 904 and 1865 A.D.: Quantitative evidence from a new South Pole ice core, Volcanism and the Earth's Atmosphere. Geophysical Monograph, 139, 165-176, 2003.

Cole-Dai, J., E. Mosley-Thompson, S. Wright, and L. Thompson, A 4100-year record of explosive volcanism from an East Antarctica ice core, J. Geophys. Res., 105(D19), 24,431-24,441, 2000.

Cole-Dai, J., E. Mosley-Thompson, and L. Thompson, Annually resolved southern hemisphere volcanic history from two Antarctic ice cores, J. Geophys. Res., 102(D14), 16,761-16,771, 1997. 
Davis, C., Y. Li, J. McConnell, M. Frey, and E. Hanna, Snowfall-driven growth in East Antarctic ice sheet mitigates recent sea-level rise, Science, 308(5730), 1898-1901, 2005.

Delmas, R., M. Legrand, A. Aristarain and F. Zanolini, Volcanic deposits in Antarctic snow and ice, J. Geophys. Res., 90(D7), 12,901-12,920, 1985.

Frezzotti, M., M. Pourchet, O. Flora, S. Gandolfi, M. Gay, S. Urbini, C. Vincent, S. Becagli, R. Gragnani, M. Proposito, M. Severi, R. Traversi, R. Udisti and M. Fily, Spatial and temporal variability of snow accumulation in East Antarctica from traverse data, J. Glaciol., 51(172), $113-124,2005$.

Frezzotti, M., S. Urbini, M. Proposito, C. Scarchilli and S. Gandolfi, Spatial and temporal variability of surface mass balance near Talos Dome, East Antarctica, J. Geophys. Res., 112, F02032, 2007.

Gao, C. et al., The 1452 or 1453 A.D. Kuwae eruption signal derived from multiple ice core records: Greatest volcanic event of the past 700 years, J. Geophys. Res., 111, D12107, 2006.

Genthon, C. and G. Krinner, Antarctic surface-mass balance and systematic biases in general circulation models, J. Geophys. Res., 106(D18), 20,653-20,664, 2001.

Genthon, C., O. Magnand, G. Krinner, and M. Fily, Do climate models underestimate snow accumulation on the Antarctic Plateau? A re-evaluation of/from in situ observations in East Wilkes Land and Victoria Land, Ann. Glaciol., 50, 61-65, 2009.

Giovinetto, M., and H. Zwally, Spatial distribution of net surface mass accumulation on the Antarctic ice sheet, Ann. Glaciol., 31, 171-178, 2000.

Helsen, M., M. van den Broeke, R. van de Wal, W. van de Berg, E. van Meijgaard, C. Davis, Y. Li and I. Goodwin, Elevation changes in Antarctica mainly determined by accumulation variability, Science, 320(5883), 1626-1629, 2008. 
Hofstede, C., et al., Firn accumulation records for the past 1000 years on the basis of dielectric profiling of six firn cores from Dronning Maud Land, Antarctica, J. Glaciol., 50(169), 279291, 2004.

Horwath, M. and R. Dietrich, Signal and error in mass change inferences from GRACE: the case of Antarctica, Geophys. J. Int., 177, 849-864, 2009.

Isaksson, E., M. van den Broeke, J.-G. Winther, L. Karlöf, J. Pinglot, and N. Gundestrup, Accumulation and proxy-temperature variability in Dronning Maud Land, Antarctica, determined from shallow firn cores, Ann. Glaciol., 29, 17-22, 1999.

Karlöf, L., et al., A 1500 years record of accumulation at Amundsenisen, Western Dronning Maud Land, Antarctica, derived from electrical and radioactive measurements on an $120 \mathrm{~m}$ ice core, J. Geophys. Res., 105(D10), 12471-12483, 2000.

Lambert, F. et al., Dust-climate couplings over the past 800000 years from the EPICA Dome C ice core , Nature, 452, 616-619, 2008.

Langway, C., K. Osada, H. Clausen, C. Hammer and H. Shoji, A 10-century comparison of prominent bipolar volcanic events in ice cores, J. Geophys. Res., 100(D8), 16241-16247, 1995.

Legrand, M. and R. Delmas, A 220-year continuous record of volcanic $\mathrm{H}_{2} \mathrm{SO}_{4}$ in the Antarctic ice sheet, Nature, 327, 671-676, 1987.

Li, Y., J. Cole-Dai, and L. Zhou, Glaciochemical evidence in an East Antarctica ice core of a recent (AD 1450-1850) neoglacial episode, J. Geophys. Res., 114, D08117, 2009.

Magand, O., C. Genthon, M. Fily, G. Krinner, G. Picard, M. Frezzotti and A. Ekaykin, An upto-date quality-controlled surface mass balance data set for the $90^{\circ}-180^{\circ} \mathrm{E}$ Antarctica sector and 1950-2005 period, J. Geophys. Res., 112, D12106, 2007. 
McConnell, J., G. Lamorey, S. Lambert, and K. Taylor, Continuous ice-core chemical analyses using Inductively Coupled Plasma Mass Spectrometry, Environ. Sci. Technol., 36, 7-11, 2002.

Monaghan, A., et al., Insignificant Change in Antarctic Snowfall Since the International Geophysical Year, Science, 313(5788), 827-831, 2006.

Moore, J., H. Narita, and N. Maeno, A continuous 770-year record of volcanic activity from East Antarctica, J. Geophys. Res., 96(D9), 17,353-17,359, 1991.

Mosley-Thompson, E., J. Paskievitch, M. Gow, and L. Thompson, Late 20th century increase in South Pole snow accumulation, J. Geophys. Res., 104(D4), 3877-3886, 1999.

Müller, K., A. Sinisalo. H. Anschütz, S.-E. Hamran, J.-O. Hagen, J. McConnell and D. Pasteris, An $860 \mathrm{~km}$ surface mass-balance profile on the East Antarctic plateau derived by GPR, Ann. Glaciol., 51(55), 2010.

Müller, K., S.-E. Hamran, A. Sinisalo, and J.-O. Hagen, L-band microwave penetration depth in polar snow, firn, and ice, submitted to Transactions on Geoscience and Remote Sensing, 2010.

Oerter, H., F. Wilhelms, F. Jung-Rothenhäusler, F. Göktas, H. Miller, W. Graf and S. Sommer, Accumulation rates in Dronning Maud Land, Antarctica, as revealed by dielectric-profiling measurements of shallow firn cores, Ann. Glaciol., 30, 27-34, 2000.

Palmer, A., T. van Ommen, M. Curran, V. Morgan, J. Souney, P. Mayewski, High-precision dating of volcanic events (A.D. 1301-1995) using ice cores from Law Dome, Antarctica, $J$. Geophys. Res., 106, D22, 28089-28095, 2001.

Picciotto, E., G. Grozaz, and W. de Breuck, Accumulation on the South Pole Queen Maud Land Traverse, 1964-1968. Antarctic Snow and Ice Studies II, Antarc. Res. Ser., 16, 257-315, 1971. 
Ren, J., J. Sun and D. Qin, Preliminary results of ionic concentrations in snow pits along the Zhongshan-Dome A traverse route, Antarctica, Ann. Glaciol., 39, 155-160, 2004.

Ren, J., C. Li, S. Hou, C. Xiao, D. Qin, Y. Li and M. Ding, A 2680 year volcanic record from the DT-401 East Antarctic ice core, J. Geophys. Res., 115, D11301, 2010.

Richardson, C., E. Aarholt, S. Hamran, P. Holmlund and E. Isaksson, Spatial distribution of snow in western Dronning Maud Land, East Antarctica, mapped by a ground-based snow radar, J. Geophys. Res., 102(B9), 20343-20353, 1997.

Rignot, E., J. Bamber, M. van den Broeke, C. Davis, Y. Li, W. van de Berg and E. van Meijgaard, Recent Antarctic ice mass loss from radar interferometry and regional climate modelling, Nat. Geosci., 1, 2008.

Stenni, B., M. Proposito, R. Gragnani, O. Flora, J. Jouzel, S. Falourd and M. Frezzotti, Eight centuries of volcanic signal and climate change at Talos Dome (East Antarctica), J. Geophys. Res., 107(D9), 4076, 2002.

Traufetter, F., H. Oerter, H. Fischer, R. Weller, and H. Miller, Spatio-temporal variability in volcanic sulphate deposition over the past $2 \mathrm{kyr}$ in snow pits and firn cores from Amundsenisen, Antarctica, J. Glaciol., 50(168), 137-146, 2004.

Turner, J., R. Bindschadler, P. Convey, G. di Prisco, E. Fahrbach, J. Gutt, D. Hodgson, P. Mayewski and C. Summerhayes (eds.), Antarctic climate change and the environment, Scientific Committee on Antarctic Research, 2009.

van de Berg, W., M. van den Broeke, C. Reijmer, and E. van Meijgaard, Reassessment of the Antarctic surface mass balance using calibrated output of a regional atmospheric climate model, J. Geophys. Res., 111, D11104, 2006. 
X - 24 ANSCHÜTZ ET AL:: ACCUMULATION VARIATION ON THE EAST ANTARCTIC PLATEAU

${ }_{493}$ Vaughan, D., J. Bamber, M. Giovinetto, J. Russell, and A. Cooper, Reassessment of net surface

$494 \quad$ mass balance in Antarctica, J. Climate, 45(150), 933-946, 1999.

${ }_{495}$ Vaughan, D., How does the Antarctic ice sheet affect sea level rise? Science, 308(5730), 1877-

$496 \quad 1878,2005$.

${ }_{497}$ Velicogna, I., Increasing rates of ice mass loss from the Greenland and Antarctic ice sheets

${ }_{498}$ revealed by GRACE, Geophys. Res. Lett., 36, L19503, 2009.

${ }_{499}$ Wilhelms, F., J. Kipfstuhl, H. Miller, H. Heinloth, and J. Firestone, Precise dielectric profiling ${ }_{500}$ of ice cores: a new device with improved guarding and its theory, J. Glaciol., 44(146), 171$501 \quad 174,1998$. 
Table 1. Snow depths of volcanic peaks in the cores from the first leg. All depth units are in meters and the date refers to the year of eruption as this is more certain than the year of deposition (see text).

\begin{tabular}{llllllllll} 
volcano & year & NUS07-1 & NUS07-2 & NUS07-3 & NUS07-4 & NUS07-5 & NUS07-6 & NUS07-7 & NUS07-8 \\
\hline Agung & 1963 & 6.44 & 3.49 & 3.00 & 2.37 & 2.72 & - & 3.39 & 3.22 \\
Krakatau & 1883 & 14.44 & 10.48 & 7.62 & 6.93 & 7.66 & 5.63 & 9.1 & 9.22 \\
Tambora & 1815 & 20.70 & 15.24 & 10.98 & 10.33 & 11.62 & 8.98 & 13.42 & 13.57 \\
Unknown & 1695 & - & 22.96 & 16.98 & 16.03 & 18.12 & 13.76 & 20.37 & - \\
Deception Island & 1641 & - & 26.02 & 20.34 & 16.92 & 20.10 & 17.03 & 23.21 & - \\
Unknown & 1622 & - & 27.27 & 22.49 & 20.39 & - & 20.32 & - & - \\
Huaynaputina & 1600 & - & 28.96 & 25.33 & - & 22.77 & - & 25.29 & - \\
Kuwae & 1453 & - & 36.19 & - & - & 29.36 & - & 32.55 & - \\
El Chichon & 1342 & - & 42.29 & - & - & 34.72 & - & 36.39 & - \\
Unknown & 1259 & - & 46.75 & - & - & 38.44 & - & 42.01 & -
\end{tabular}

Table 2. Snow depths of volcanic peaks in the cores from the second leg. All depth units are in meters and the date refers to the year of eruption.

\begin{tabular}{|c|c|c|c|c|c|c|}
\hline volcano & year & NUS08-2 & NUS08-3 & NUS08-4 & NUS08-5 & NUS08-6 \\
\hline Agung & 1963 & 7.19 & 5.51 & 4.92 & 4.76 & 7.33 \\
\hline Krakatau & 1883 & 18.10 & 12.17 & 11.70 & 11.39 & 14.31 \\
\hline Tambora & 1815 & 26.91 & 17.84 & 16.83 & 16.32 & 18.02 \\
\hline Unknown & 1695 & - & 25.85 & 25.19 & 24.25 & - \\
\hline Deception Island & 1641 & - & 29.27 & 28.43 & 27.61 & - \\
\hline Unknown & 1622 & - & - & 29.71 & 28.86 & - \\
\hline Huaynaputina & 1600 & - & - & - & 29.94 & - \\
\hline Kuwae & 1453 & - & - & - & 38.05 & - \\
\hline El Chichon & 1342 & - & - & - & 43.98 & - \\
\hline Unknown & 1259 & - & - & - & 48.40 & - \\
\hline
\end{tabular}


Table 3. Accumulation over the most recent decades, 200-year mean and long-term mean in the NUScores, compared with the results by Arthern et al. [2006]. The 200-year values for sites NUS07-1, -3, -4 and -6 have been taken from Anschütz et al. [2009].

\begin{tabular}{|c|c|c|c|c|c|c|c|}
\hline core name & lat. & long. & $\begin{array}{l}\text { elevation } \\
\text { m a.s.l. }\end{array}$ & $\begin{array}{l}\text { acc. } 1963-2007 / 08 \\
\operatorname{kg~m}^{-2} \mathbf{a}^{-1}\end{array}$ & $\begin{array}{l}\text { acc. } 1815-2007 / 08 \\
\operatorname{kg~m}^{-2} \mathbf{a}^{-1}\end{array}$ & $\begin{array}{l}\text { long-term acc. } \\
\mathbf{k g ~ m}^{-2} \mathbf{a}^{-1}\end{array}$ & $\begin{array}{l}\text { acc. from Arthern et al. [2006] } \\
\mathbf{k g ~ m}^{-2} \mathbf{a}^{-1}\end{array}$ \\
\hline NUS07-1 & $73^{\circ} 43^{\prime} \mathrm{S}$ & $07^{\circ} 59^{\prime} \mathrm{E}$ & 3174 & $55.9 \pm 3.9$ & $52.0 \pm 2.0$ & - & 58 \\
\hline NUS07-2 & $76^{\circ} 04^{\prime} \mathrm{S}$ & $22^{\circ} 28^{\prime} \mathrm{E}$ & 3582 & $28.0 \pm 2.0$ & $33.0 \pm 0.7$ & $33.3 \pm 1.2^{1}$ & 42 \\
\hline NUS07-3 & $77^{\circ} 00^{\prime} \mathrm{S}$ & $26^{\circ} 03^{\prime} \mathrm{E}$ & 3589 & $23.7 \pm 1.7$ & $22.0 \pm 0.5$ & $27.8 \pm 1.0^{2}$ & 40 \\
\hline NUS07-4 & $78^{\circ} 13^{\prime} \mathrm{S}$ & $32^{\circ} 51^{\prime} \mathrm{E}$ & 3595 & $17.5 \pm 1.2$ & $19.0 \pm 0.5$ & $20.9 \pm 0.8^{3}$ & 36 \\
\hline NUS07-5 & $78^{\circ} 39^{\prime} \mathrm{S}$ & $35^{\circ} 38^{\prime} \mathrm{E}$ & 3619 & $20.1 \pm 1.4$ & $24.0 \pm 0.5$ & $26.0 \pm 0.9^{1}$ & 37 \\
\hline NUS07-6 & $80^{\circ} 47^{\prime} \mathrm{S}$ & $44^{\circ} 51^{\prime} \mathrm{E}$ & 3672 & - & $16.0 \pm 0.4$ & $21.1 \pm 0.7^{2}$ & 32 \\
\hline NUS07-7 & $82^{\circ} 04^{\prime} \mathrm{S}$ & $54^{\circ} 53^{\prime} \mathrm{E}$ & 3725 & $26.1 \pm 1.9$ & $29.4 \pm 0.6$ & $29.5 \pm 1.0^{1}$ & 30 \\
\hline NUS07-8 & $84^{\circ} 11^{\prime} \mathrm{S}$ & $53^{\circ} 32^{\prime} \mathrm{E}$ & 3452 & $30.0 \pm 2.1$ & $32.0 \pm 1.2$ & - & 40 \\
\hline NUS08-2 & $87^{\circ} 51^{\prime} \mathrm{S}$ & $01^{\circ} 48^{\prime} \mathrm{W}$ & 2583 & $63.4 \pm 4.2$ & $67.4 \pm 2.6$ & - & 65 \\
\hline NUS08-3 & $84^{\circ} 08^{\prime} \mathrm{S}$ & $21^{\circ} 54^{\prime} \mathrm{E}$ & 2625 & $45.3 \pm 3.1$ & $40.1 \pm 1.0$ & $38.8 \pm 1.4^{4}$ & 43 \\
\hline NUS08-4 & $82^{\circ} 49^{\prime} \mathrm{S}$ & $18^{\circ} 54^{\prime} \mathrm{E}$ & 2552 & $36.1 \pm 2.1$ & $36.7 \pm 0.9$ & $37.2 \pm 1.3^{3}$ & 34 \\
\hline NUS08-5 & $82^{\circ} 38^{\prime} \mathrm{S}$ & $17^{\circ} 52^{\prime} \mathrm{E}$ & 2544 & $37.6 \pm 2.3$ & $35.0 \pm 0.8$ & $35.5 \pm 0.8^{1}$ & 34 \\
\hline NUS08-6 & $81^{\circ} 42^{\prime} \mathrm{S}$ & $08^{\circ} 34^{\prime} \mathrm{E}$ & 2447 & $49.2 \pm 3.4$ & $39.2 \pm 1.5$ & - & 41 \\
\hline
\end{tabular}

\footnotetext{
${ }^{1} 1259-2007 / 08$

${ }^{2} 1600-2007 / 08$

${ }^{3} 1622-2007 / 08$

${ }^{4} 1641-2007 / 08$
} 


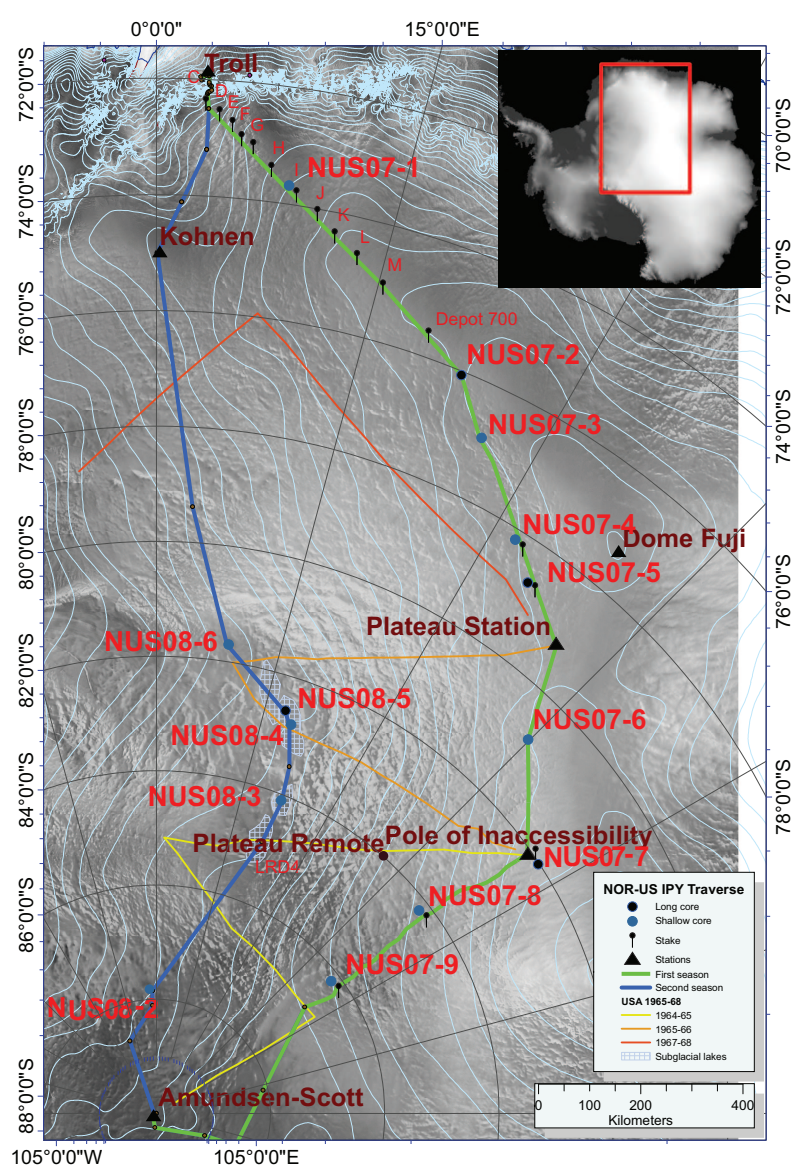

Figure 1. Map of the traverse route 2007/2008 (green line) and 2008/2009 (blue line) with drill sites from both legs indicated (NUS07-X and NUS08-X). The South Pole Queen Maud Land Traverse routes [Picciotto et al., 1971] are indicated by the yellow-orange lines and relevant stations in the area of investigation are shown as well. Other dots indicate science stops along the traverse routes not relevant for this paper but shown for the sake of completeness. Elevation contour lines are in $100 \mathrm{~m}$ intervals. The map was compiled by K. Langley and S. Tronstad (Norwegian Polar Institute). 


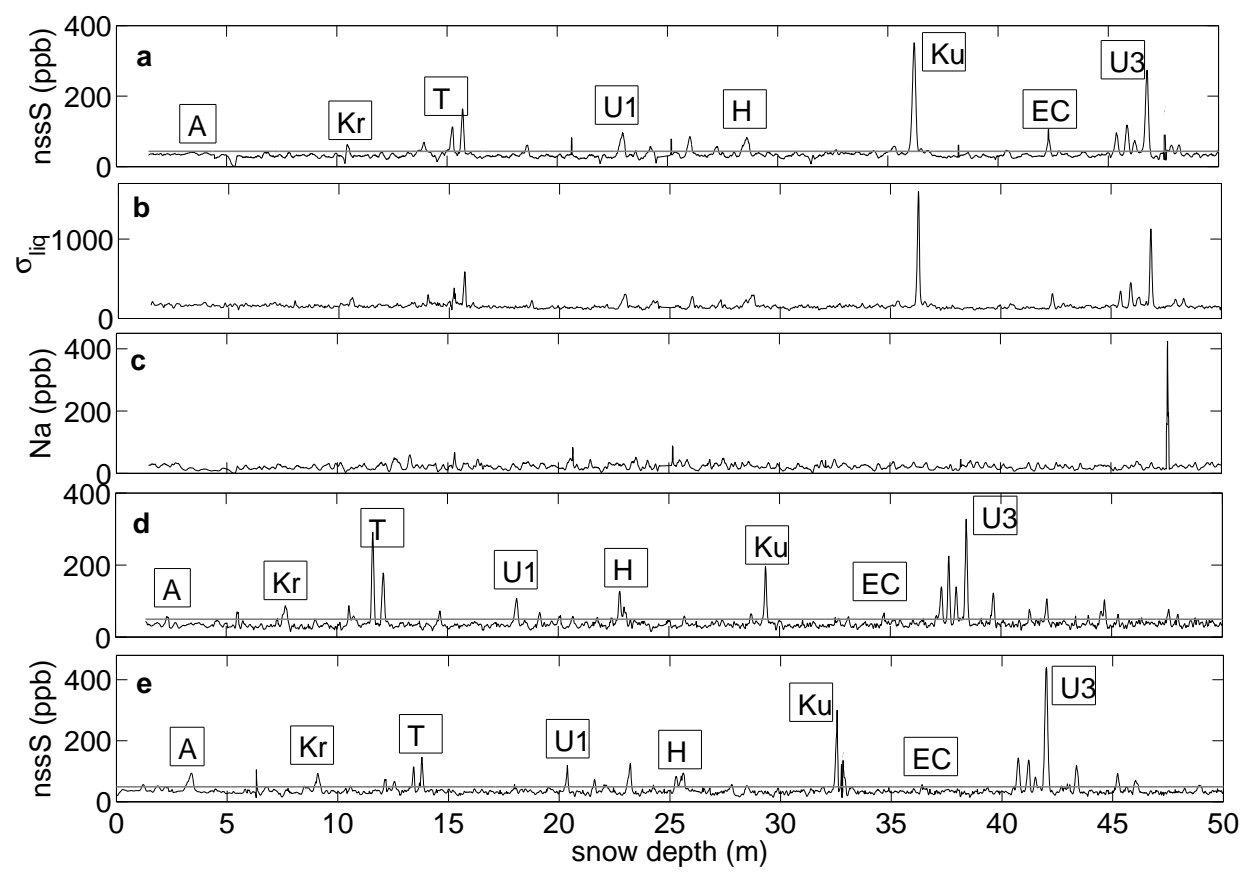

Figure 2. Records of chemistry data for the cores NUS07-2 (a: nss-sulfur, b: electrolytical conductivity, c: sodium), NUS07-5 (d: nss-sulfur) and NUS07-7 (e: nss-sulfur). The two-fold standard deviation is indicated by the grey line in the sulfur records. A: Agung 1963, Kr: Krakatau 1883, T: Tambora 1815, U1: Unknown 1695, H: Huaynaputina 1600, Ku: Kuwae 1453, EC: El Chichon 1342, U3: Unknown 1259 . Note that only the top $50 \mathrm{~m}$ are shown here as they fully cover the time period we are concerned with here. 

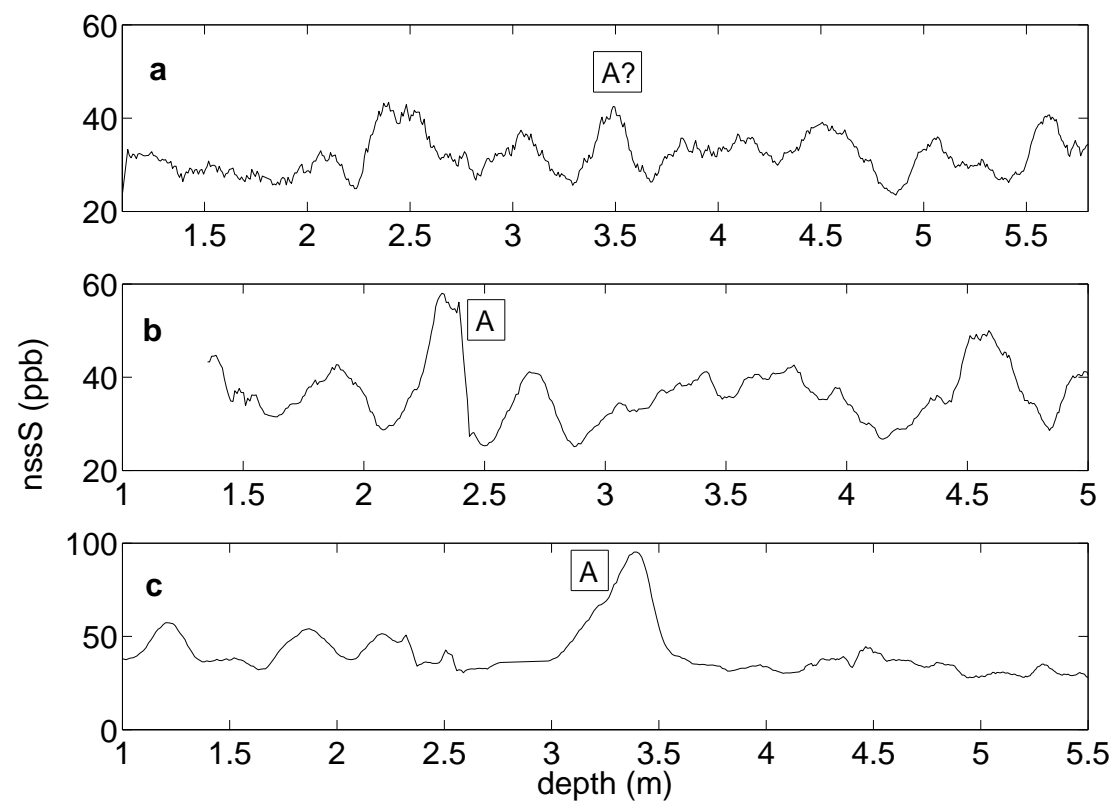

Figure 3. The Agung eruption in the deep cores from the first leg. a) NUS07-2, b) NUS07-5, c) NUS07-7. Since the peak in NUS07-2 is just at the two-fold standard deviation (see Figure 2) and also less clear than in the other cores, it is displayed with a question mark here. 


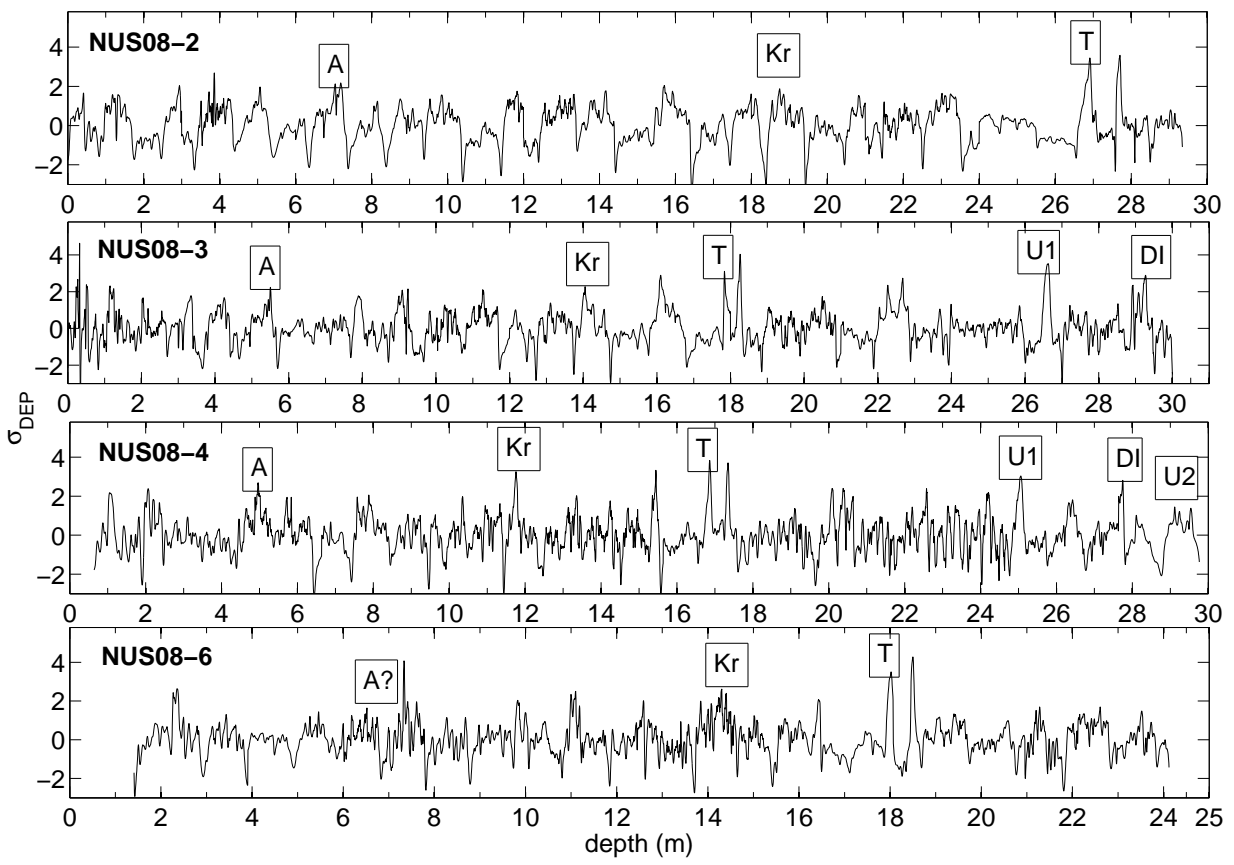

Figure 4. Normalized DEP-based conductivity for the cores NUS08-2, $-3,-4$ and -6 from the second leg. The volcanoes discussed in the text are indicated. DI: Deception Island 1641, U2: Unknown 1622; other abbreviations see Figure 2. The negative spikes in parts of the records are due to varying core quality and slightly differing diameter and are not eliminated here completely as full elimination would induce data gaps. 


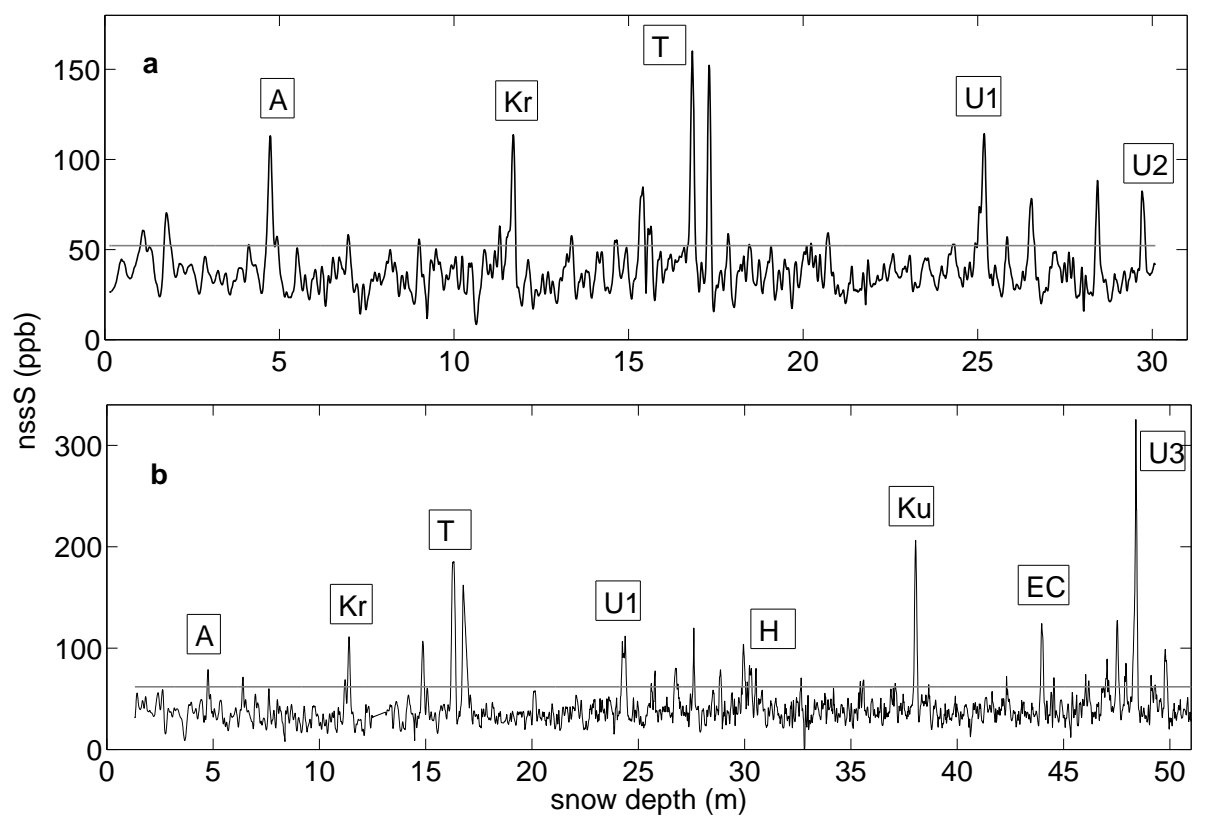

Figure 5. Sulfur data for the cores NUS08-4 (a) and NUS08-5 (b) from the second leg. The two-fold standard deviation is indicated by the grey line. Same abbreviations as in Figure 2. Note that only the top $50 \mathrm{~m}$ of NUS08-5 are displayed here, covering the period back to about 1250 AD that we are concerned with in this paper.

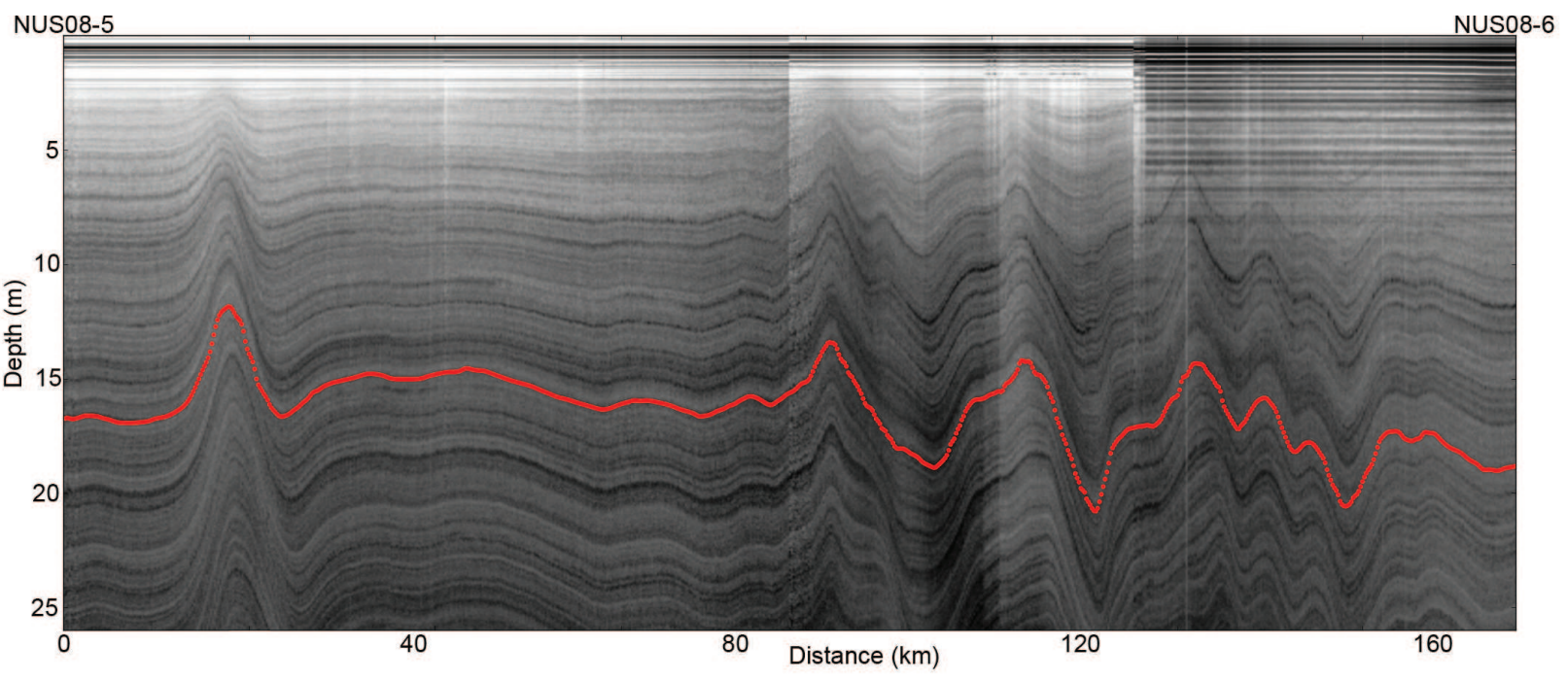

Figure 6. Radargram of the stretch between NUS08-5 and -6. The Tambora layer is highlighted by the red dashed line. 


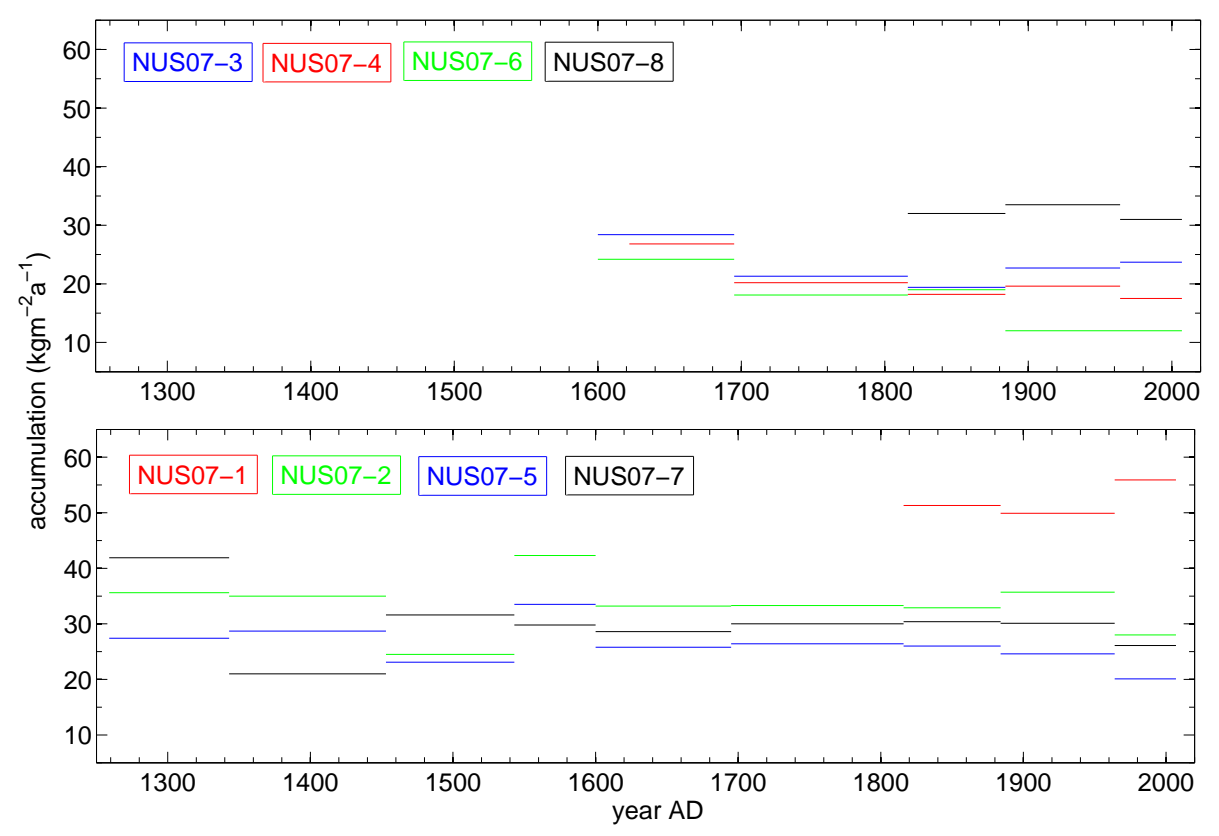

Figure 7. Temporal variability of accumulation rate in the cores from the first leg. Top: DEP cores; bottom: chemistry cores.

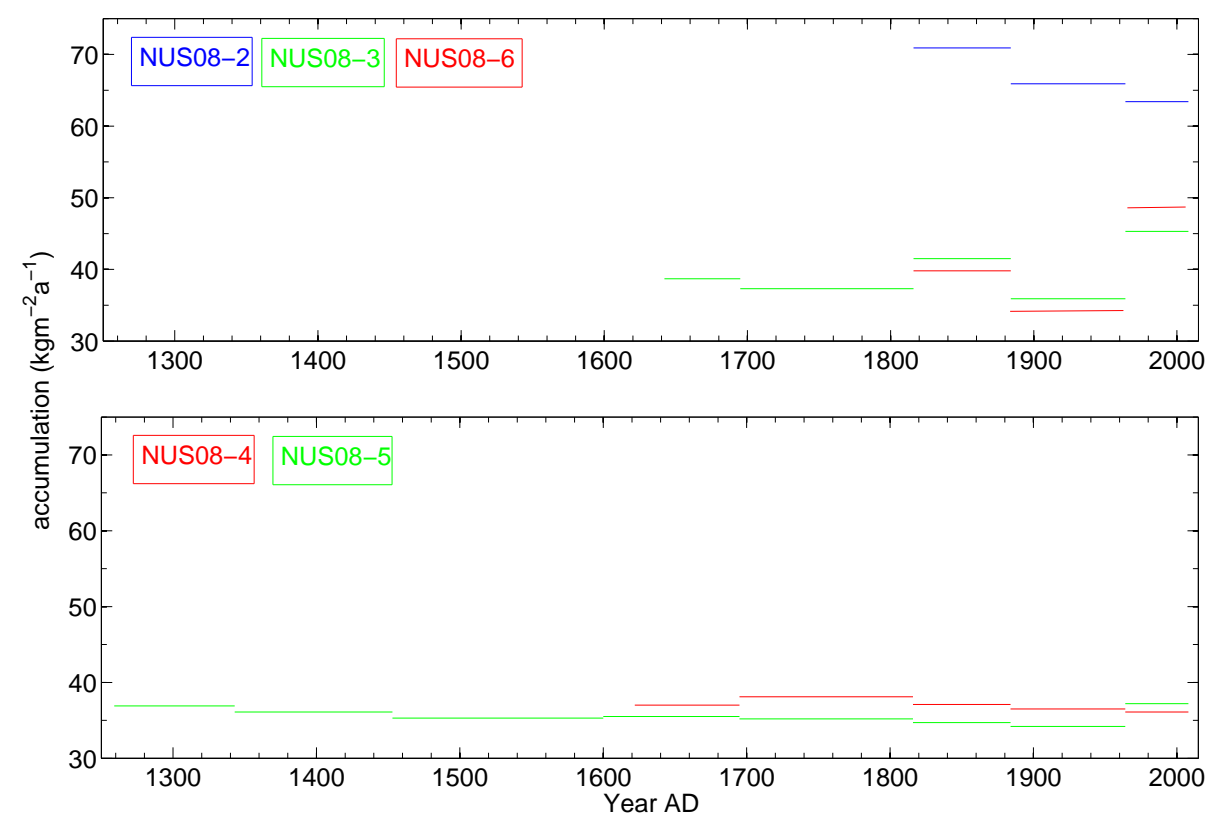

Figure 8. Temporal variability of accumulation rate in the cores from the second leg. Top: DEP cores; bottom: chemistry cores. 